\title{
Vascular Plants of the Maritime Antarctic: Origin and Adaptation
}

\author{
Ivan Parnikoza ${ }^{1}$, Iryna Kozeretska ${ }^{2}$, Viktor Kunakh ${ }^{1}$ \\ ${ }^{1}$ Institute of Molecular Biology and Genetics of National Academy of Sciences of Ukraine, Kyiv, Ukraine; ${ }^{2}$ Taras Shevchenko \\ National University of Kyiv, Ukraine. \\ Email: parnikoza@gmail.com
}

Received April $7^{\text {th }}, 2011$; revised May 24 $4^{\text {th }}, 2011$; accepted August $15^{\text {th }}, 2011$.

\begin{abstract}
The question of why only two species of vascular plant have colonized Antarctica has not been fully answered. This review is based on a series of parallel analyses of distribution, ecology, and adaptation on the morphological, cellular, and molecular genetic levels, and addresses the causes of the exclusive adaptation of Deschampsia antarctica Desv. (Poaceae) and Colobanthus quitensis (Kunth) Bartl. The authors conclude that the unique distribution of these species, including the Antarctic Peninsula, is not related to the presence of any specific mechanisms of adaptation to the extreme environment, but rather is a result of a gradual adaptation of these taxa to the extreme conditions during the development of glacial events and wide distribution and a substantial seed bank which could ensure mosaic survival in some ice-free areas, as well as survival through several years of snow and ice cover. Glaciological, molecular, population and reproduction biology studies are still necessary to deepen our understanding of the timing of the colonization of the region by vascular plants. However, keeping in mind that molecular methods alone are unlikely to give exhaustive evidence, application of other adequate methods in the context of the history of Pleistocenic glaciation in the region is also necessary to answer the question.
\end{abstract}

Keywords: Deschampsia antarctica, Colobanthus quitensis, Unique Adaptation, Time of Colonization, Gradual Adaptation

\section{Introduction}

Antarctica, due to its geographical separation from other continents and the presence of the oceanic polar frontal zone and the Antarctic Circumpolar Current, is an isolated continent [1-3]. The part of the continent where the monthly mean temperature in the summer rises above zero is separated into a distinct zone-the maritime Antarctic $[1,4]$. Whilst the majority of the Antarctic continent is covered by permanent ice and snow, only $2 \%$ of the landmass is available for colonization by plants and animals [5]. The maritime Antarctic ecosystems host two species of flowering plants: the Antarctic hairgrass (Deschampsia antarctica Desv., Poaceae) and the Antarctic pearlwort (Colobanthus quitensis Kunth. Bartl., Caryophyllaceae) [6]. It is generally assumed that these species have colonized this region by means of long distance dispersal during the Holocene $[1,7,8]$. However, the fact that these species are the only flowering plants present in the native flora of this region raises the question of why no other species characteristic of the southern sub-polar regions have colonized the maritime Antarctic within the period since the last glacial maximum [7,9], as a wide range of other vascular plant species are known to be present in the neighboring sub-Antarctic [7,70]. The same latitudes in the Arctic, with its equally inclement habitats, host a much larger list of vascular plant species [11].

A further complication is added by the recent rapid warming periods in the region over the last 50 years [12]. This warming has equaled the most rapid rates globally, demonstrating a rise of $3^{\circ} \mathrm{C}$ annually along the western coast of the Antarctic Peninsula [3,13-17]. Nonetheless, a dispersal of other species adapted to polar climate has not happened $[7,9]$. Only expansive weeds such as Poa annua $\mathrm{L}$. and $P$. pratensis L. that lack any signs of appropriate adaptation to polar environments have been able to afford human-mediated colonization of this region [9]. However, no considerable expansion beyond the zone of primary invasion of the only live population of $P$. апnиa in the region has happened since more than 20 years ago $[1,18,19]$. Reports about other species encounters in Antarctica appear from time to time, e. g. the finding of $\mathrm{Na}$ ssauvia magellanica J. F. Gmelin (Asteraceae) of Patago- 
nian origin on Deception Island (Downie, personal communication, 2009). However, as a rule, such colonists are not known to survive for longer than one season $[1,7]$. Interestingly, experiments with artificial transplantation of the Patagonian and sub-Antarctic species to the region have not been successful $[7,9,20]$.

Profound adaptation to Antarctic conditions, dependence on mycorhizas, as well as notable isolation, have been put forth as the possible reasons for the lack of vascular plants in this region [7,9]. However, the question has not been answered yet and, in this review, we analyse a body of evidence available across the bio-logical disciplines, in order to clarify the existence and the importance of the specific traits of D. antarctica and $C$. quitensis that ensure their survival and apparent success in this region.

\section{Systematics and Areal}

The genus Deschampsia comprises 30 to 40 species distributed both in the Northern and the Southern Hemispheres, the majority of which are perennials, though there is a group of annual species as well [21-24]. Annuals from the Alps are supposed to have evolved from perennial ancestors which had migrated from the plains. The genus belongs to the Tribe Avenae, which is very diverse in the Northern Hemisphere, although the genus Deschampsia is more diverse in the Southern [22]. Taxonomic studies have shown that it is necessary to separate the genus Avenella from Deschampsia [22,25]. Recent molecular phylogenetic studies have concluded that D. antarctica from South America, sub-Antarctica and the maritime Antarctic is closely related to the species from southern Argentina and Chile: D. parvula (Hook. f.) Desv. and D. venistula Parodi. Another closely related branch comprises D. laxa Phil., D. kinga (Hook. f.) Desv., $D$. berteroana F. Meigen from central Chile, $D$. tenella Petrie from New Zealand, and the South American races of D. caespitosa (L.) P. Beauv. [21,22]. Our study species- $D$. antarctica-is morphologically different from the other species of the genus from the subAntarctic and the Andes, namely D. caespitosa, D. chapmani Petrie, and D. penicellata $n$. sp.; the differences lie in the size of the stem, leaves, and the flower parts [26].

The distribution area of $D$. antarctica encompasses Argentina, Chile and Peru. The species is also found on Tierra del Fuego and the surrounding islands, the Falkland Islands, South Georgia, the South Orkney Islands, the South Shetland Islands. It is also present on one of the islands of the South Sandwich Islands archipelago, as well as along the western coasts of the Antarctic Peninsula and the adjacent archipelagos of the maritime Antarctic, reaching to the south Lazarev Bay on Alexander Island [26; Convey, personal communication, 2008].
The genus Colobanthus Bartl. is distributed mainly in the Southern Hemisphere (only C. quitensis is listed in Mexico). Different authors give different numbers of species in the genus Colobanthus [26]. Thus, for South America the list varies up to 13 species, part of which are now included in Colobanthus quitensis and the rest in $C$. subulatus (D'Urv.) Hook. f. Of all the species of the genus, only C. quitensis is found in the maritime Antarctic, again reaching Lazarev Bay on Alexander Island [Convey, personal communication, 2008]. C. subulatus is dispersed to the south up to South Georgia [26]. Overall, the genus consists of up to 20 species [27].

Other species of the genus that are related to $C$. quitensis are found on Kerguelen with the adjoining islands, as well as on Heard Island-C. kerguelensis Hook. f., Tasmania, New Zealand, sub-Antarctic islands of the Australian sector-C. muscoides Hook. f., Macquarie Island-C apetalus (Labill.) Druce., as well as on the Falkland Islands, Tierra del Fuego, and Patagonia up to the latitude of $52^{\circ} 25^{\prime} \mathrm{S}-C$. subulatus [26,28]. C. quitensis differs from these species in a number of morphological traits: the character of leaf tips, the leaf width, the relative length of the sepal and the seed capsule, and the sepal count [26].

C. quitensis and D. antarctica are characterized by significant interpopulation variability of the traits mentioned above, which was the reason to separate the species into a set of derivative species by early studies. The distribution area of $C$. quitensis encompasses Mexico, the highland regions of Ecuador, Bolivia, Chile, and Peru. It is also present on Tierra del Fuego, the Falkland Islands, South Georgia, the South Orkney Islands, the South Shetland Islands, as well as along the west coast of the Antarctic Peninsula with the adjacent archipelagos [26].

In the maritime Antarctic, along the west coast of the Antarctic Peninsula, and on the adjacent islands the distribution density of the populations of both species of vascular plants is heterogeneous. Their populations are primarily located in the following three regions: 1) the South Shetland Islands; 2) in the region between Cierva Point and Cape Garcia; and 3) near Marguerite Bay. Detailed maps of the distribution of both species in the region have been provided by a number of authors [20, 29-33].

\section{Ecology and reproduction}

The habitat of the vascular plants and the plant communities they create is largely defined by the climate of the region. As a result of the influence of the circumpolar current a branch of which creates a buffering effect by alleviating the temperature fluctuations in the region, the climate of this part of Antarctica is oceanic [1]. Nevertheless, January is the only month when the mean air 
temperature rises above zero. At the same time, the air temperature rarely drops below $-15^{\circ} \mathrm{C}$ during the coldest months (June through September). In this region, the negative temperatures may occur at any time throughout the year. However, even slight declensions in the landscape may play a crucial role in creating a microclimate due to the low position of the sun in Polar zone. These and other specific traits cause a variegated mosaic of microclimates, often differing even between the neighboring islands [10].

Vascular plant vegetation areas are represented by rocky slopes, moraines, simple soils (including peats) and pebble beaches free of ice and the summer snow cover. At smaller scales, plants can root on cliff ledges and in crevices [20,29-31,34-37].

Both species appear not to be very demanding with regards to the Antarctic soil characteristics. Nevertheless, the slow organics decomposition processes driven by invertebrates and fungi that take place in this substrate still allow drawing an analogy line between this substrate and soils [38]. Based on the main source of organics inflow, maritime Antarctic soils can be divided into two basic groups: those formed under the Antarctic plant communities [39] and ornithogenic. The latter are formed in barren bird colony areas and are characterized by high organics content [40].

Regarding the organics content in the soil, both vascular plant species of the region inhabit locations within very wide ecological amplitude. This equally applies to the content of microelements and trace metals [41-43].

Vascular plants develop a special Antarctic herb tundra formation which comprises a single grass and tuft chamaephyte sub-formation $[6,10]$.

The plant starts tillering out early, producing shoots. Young shoots are contained inside the leaf sheath. Leaves are sessile, linear. The plant has bisexual flowers gathered into tight acervuli. The species is considered self-pollinating. Its flowers remain closed, so that self-pollination makes for cleistogamy [44]. However, based on up-todate data, the possibility of cross-pollination can not be completely excluded, as in South America both cleistoand chasmogamic flowers have been shown for this species [45]. Chasmogamy may sometimes occur during the mild seasons in Antarctica as well, as the ratio between forming cleistogamic and chasmogamic (capable of crosspollination) flowers in other plant species has been shown to depend on the environmental conditions [46,47]. In the Antarctic conditions, the development of $D$. antarctica begins in November when seed germination and recovery of last-year tufts starts [45].

The species is capable of vegetative propagation by means of tuft outgrowth and split-off of the tuft parts. $D$. antarctica plants often form a single dense and contigu- ous tuft, which area varies from one to several hundred square meters. A die-off of the plants in the central parts of the tuft has also been documented. An uprooted plant is capable of re-establishing after being transported to another appropriate place [48]. As a result of this ability, the possibility of plant dispersal by birds (as a nest building material) has repeatedly been suggested $[7,13,48]$.

C. quitensis is a perennial flowering plant which forms dense low rounded hemispheric tufts and lives up to 35 40 years. This plant has a tap root, is almost incapable of vegetative reproduction [49] and has an age structure similar to that of $D$. antarctica $[37,50]$. The species, in most if not all cases, is a self-pollinator. Its stamens arranged in front of the pistil make for a high probability of cleistogamy, which leads to inbreeding. The seed yield resulting from one self-pollination event is rather high: near 43 seeds per capsule in plants from Tierra del Fuego and the Ands [26].

There is almost no evidence of vegetative reproduction in C. quitensis, and all studied populations seem to have originated from seeds. Under favorable conditions, seeds of this species can survive for a long time. The germination temperature may be high. Seed germination disruption in $C$. quitensis has been observed when the temperature dropped from $9^{\circ} \mathrm{C}$ to $2^{\circ} \mathrm{C}$ [49].

In $C$. quitensis, just like in other perennials with slow growth in extreme environments, the appearance of new plants from seeds occurs only in some years [49]. Nonetheless, this is the groundwork of its population renewal [11]. Studies of the population structure of C. quitensis have revealed its extreme irregularity. Low reproduction rates are common for Antarctic and highland plants, as the success of seed reproduction and seedling survival are severely restricted by the unfavorable climatic factors. It has been shown that on some islands the reproductive success of $C$. quitensis depends on the conditions during a particular year. This species blossoms irregularly on the Argentine Islands and in other places of the maritime Antarctic. In some years, high seedling mortality has been registered. A successful seed reproduction is rare in such species, being almost exceptional [51]. Thus, it has been demonstrated for nine Arctic herb species that the proportion of flowering plants varies from year to year in the range between 0 and $40 \%$, and the percent of surviving seedlings - between 0 and 96\% [49].

In the case of the species discussed, dispersal of tufts by birds may also be possible. The modelling of this kind of dispersal of $C$. quitensis tufts that the authors carried out in different zones of Point-Thomas Oasis demonstrated that their successful rooting is possible on relatively wet areas of the ice-neighboring zone [48]. An increased fitness of both species under the dynamic conditions of the Antarctic environment may also be pro- 
moted by their ability to form seed banks yet described within the region [52]. Meanwhile, newcomer species can not generate a sufficiently large seed bank, and consequently a sufficient number of populations, in time, which doesn't favor their establishment and may cause early elimination, just like it happened, for instance, to a population of Poa апnиa that had survived through 13 years and was obliterated in 1967 by a volcano eruption on Deception Island [9].

Development of mycorrhiza cannot be considered as unique adaptation factor for either of the species as is not a specific process, and the fungi revealed are not unique to these vascular plants due to their vast distribution in the nearby sub-Antarctic [53].

Overall, the life forms, ontogeny, and reproduction of the Antarctic vascular plants do not show any radical distinction from other closely related or having the same life-form species of the Polar Regions or the highlands [11,54], whose reproductive biology is well adapted to the inclement environment of their habitat.

\section{Anatomical and Biochemical Adaptation}

The investigation of both Antarctic flowering plant species has not revealed any traits that could allow for a qualitative distinction from the other polar species and would explain the better survival of these species in the most inclement regions on Earth [55-57]. In general, their anatomy is characteristic of the plants inhabiting arid places. Leaves have stomata and their upper sides are coated with a thick layer of wax, which is one of the traits representative of the drought-resistant plants. The hairgrass is known to have a wide range of individual forms which differ by the chloroplast count in the cells of the inner leaf tissue-mesophyll. The number of chloroplasts negatively correlates with such parameters of the environment as short daylight hours and low average annual temperatures [57].

Peculiar traits of the photosynthetic system of both species have been a separate study topic. In general, the photosynthetic system of vascular plants is well adapted to work under low temperatures. However in these Antarctic species it becomes photosynthetically inactive when the temperature drops below $-2^{\circ} \mathrm{C}$, just like in all other vascular plants $[9,58]$.

The search for the reasons of this uniqueness was directed towards the biochemical adaptations to living under low temperatures and severe UV-exposure conditions [59]. In doing this, the majority of researchers addressed $D$. antarctica, and to a much lesser degree C. quitensis. On the biochemical level, $D$. antarctica has a system of adaptations typical, to a varying extent, of all cold habitat plants. There is a group of stabilizer hydrophylic proteins-dehydrines-the intensity of synthesis of which alters under a low temperature stress [60] and for which there are several genes identified in the hairgrass. One part of the products of these genes accumulates under an external influence by abscisic acid (ABA), and another part-under osmotic and salt stress, which is demonstrated by the presence of an ABA-dependent and ABAindependent pathways of dehydrine synthesis regulation. Analysis of the pool of these proteins has identified seven stress proteins accumulating under the low temperature stress in vascular and tectorial tissues where the zones of initial ice formation are found [61].

It has been shown that heat shock proteins $(70 \mathrm{kDa})$ also accumulate in $D$. antarctica under the temperature stress and may well explain its low photosynthetic optimum temperature $\left(+13^{\circ} \mathrm{C}\right)[5,62]$.

Tests for the presence of anti-freeze proteins typical for plants (irrespective of the area of their distribution) in D. antarctica have revealed their proportion in the general protein pool to be rather high [63]. Additionally, an IRIPs (recrystallization inhibition proteins) gene has also been identified in $D$. antarctica which codes for a protein that inhibits water recrystallization in the extracellular space. However, the protein is not species-specific [64].

Sequences have been identified in the $D$. antarctica genome which are homologous to the sequence of the genes coding for ubiquitin-like proteins. In plants, these proteins participate in the ubiquitin-ATP-dependent protein degradation and, in particular, prevent self-fertilization and are involved in reactions to stress [65]. Under low temperatures, activation of antioxidant enzymes [66] and soluble carbohydrate accumulation in tissues [59] have been revealed as well. A gene has been studied in $D$. antarctica which codes for the saccharophosphatesynthetase enzyme. The activity of the enzyme is known to increase in response to low temperature, although its quantity and the expression of the gene remain stable [67].

Investigation of the lipid composition of the $D$. antarctica membranes has not revealed any special lipids. However the phosphatidyl glycerol content is lower, which is commonly linked to higher sensitivity to stress [68]. A comparison between the pigment-protein complexes of the thylacoid membranes of $D$. antarctica and Pisum sativum L. [69] has not revealed any differences either. At the same time, quantitative differences have been found in the general content of different pigment-protein complexes [70]. D. antarctica's defence against UV-exposure is activated by means of an increase in $\beta$-carotene content and a reduction of violaxanthin, as shown for the UV-treated leaves. The role of carotenoids may be linked to the defensive increase in thylacoid membrane fluidity as a reaction to damage produced by oxygen upon exposure [71]. An increase in flavonoid content has also been shown as a mechanism of defence against UV-exposure, 
however this type of reaction is not specific to Antarctic plants [72].

Gene database search (GenBank, TrEMBL, and SwissProt (http://www.expasy.org; Supplement 2) revealed 37 amino acid sequences that can be determined which are part of the $D$. antarctica proteome. Of these, 20 sequences are potential proteins or protein fragments with a predicted function, and 17 sequences are potential proteins or protein fragments whose function has been determined. It has been shown for $D$. antarctica that the transcripts of 25 genes previously described for other species appear as a reaction to cold [73]. The analysis performed shows that the annotation of the genome and the proteome of $D$. antarctica is in its initial stage, and the functions of most known potential proteins have yet to be determined [70,73].

\section{Cytogenetic Traits}

The total chromosome number of the species of the genus Deschampsia is usually $2 n=26$, with the basic count $\mathrm{X}=13$. There are only some species with the basic chromosome count 7 , such as $D$. artropurpurea $(2 n=14)$ and $D$. flexuosa (commonly $2 n=28$ ), which, according to molecular taxonomy data, are isolated as separate genera $[22,24,74]$ (Table 1).

Differences between the Deschampsia core and D. atropurpurea and $D$. flexuosa have been demonstrated by studying isozyme spectra, C-banding, and using methods of plastid and nuclear DNA restriction patterns [22,24].

Analysis of the data in Table 1 reveals that irrespective of the areal (and in the majority of cases the species of the genus are adapted to living in cold wet meadow habitats) speciations were not accompanied by changes in chromosome numbers. However, polyploidization and aneuploidization of the genome have been found. Karyological variations in the species of the genus Deschampsia, namely $D$. caespitosa, are caused by the ability of smaller chromosomes to merge with subsequent polyploidization [22,77]. Based on this, Poaceae have been attributed traits of ecological differentiation linked to ploidy, with diploid plants having lower degrees of potential realization of their niche than polyploids. The degree of this realization increased with an increase in ploidy [78]. It seems like it is this trend that lies at the mainstay of the appearance of new species forms that are known to have only tetraploid (with $n=13$ ) karyotype, such as for instance D. obensis, D. mackenziana, and D. mildbraedii (Table 1).

The high proportion of aneuploids and the variation of the diploid chromosome count from 18 to 26 have also been shown by cytological analysis for $D$. caespitosa from northern Lake Ontario populations (Canada). Be- sides, individuals with $2 n=26$ are known to contain additional so-called B chromosomes. The role of the latter, also identified in the genome of $D$. wibeliana, remains unclear $[75,79]$. In some specific habitats polyploidization has been found to lead to isolation of endemic forms [76].

Regarding $D$. antarctica, its karyotype, according to the only data available up to date [24], is $2 n=2 x=26$, with the karyotype formula $10 \mathrm{~m}+6 \mathrm{~cm}+2 \mathrm{t}$. The nucleolar organizer region is located on the short arm of one of the submetacentric chromosome pairs which form a terminal satellite. The authors have also detected aneuploidy (aneusomy). The investigation of the secondary roots in D. antarctica from Galindez, Petermann, and Berthelot islands (the location of Ukrainian Vernadsky station, the maritime Antarctica) elucidated the whole picture. Additionally, polysomy has also been revealed. The chromosome count variation in root radix meristem cells was rather high-from 10 to 68 chromosomes. Therefore, D. antarctica from this region not only demonstrates polysomy with a range of variability of the chromosome count comparable to that of the genus, but is also characterized by frequent aneuploidy [80].

It is generally believed that species with low DNA content are better adapted to lower temperatures, i.e. DNA content may be considered as one of the factors that influence geographical distribution [7]. D. antarctica's low DNA content $(10 \mathrm{pg})$ does indeed characterize the species as one preadapted to develop in cold habitats [81].

A reaction of the plant's leaf tissue interphase cells to alterations in environmental conditions has been demonstrated. Analysis of DNA content in the nuclei of leaf parenchymal and epidermal cells in plants from different populations from the Argentine Islands and the Point Thomas oasis has revealed statistically significant differences of this parameter in plants from different places. Therefore, with regards to nuclear DNA content (the degree of ploidy) the genus Deschampsia, including $D$. antarctica, is a complex heterogenous entity. Ploidy and DNA content vary significantly, which, in our opinion, is of adaptive importance [42]. This is congruent with the ideas about the mechanisms and causes of these phenomena proposed by other authors who link the observed aneusomy to the differential influence of environmental factors, temperature in particular (see discussion in [24]).

Regarding C. quitensis, its $2 n$ chromosome set includes 80 chromosomes. Due to the small size of the chromosomes, karyotype investigation has not been completed so far. Near 80 chromosomes have been found in other close species, such as C. apetalus and C. affinus [26]. 
Table 1. Chromosome numbers of Deschampsia genus species, and its general distribution and ecological grow conditions [24, 74-76].

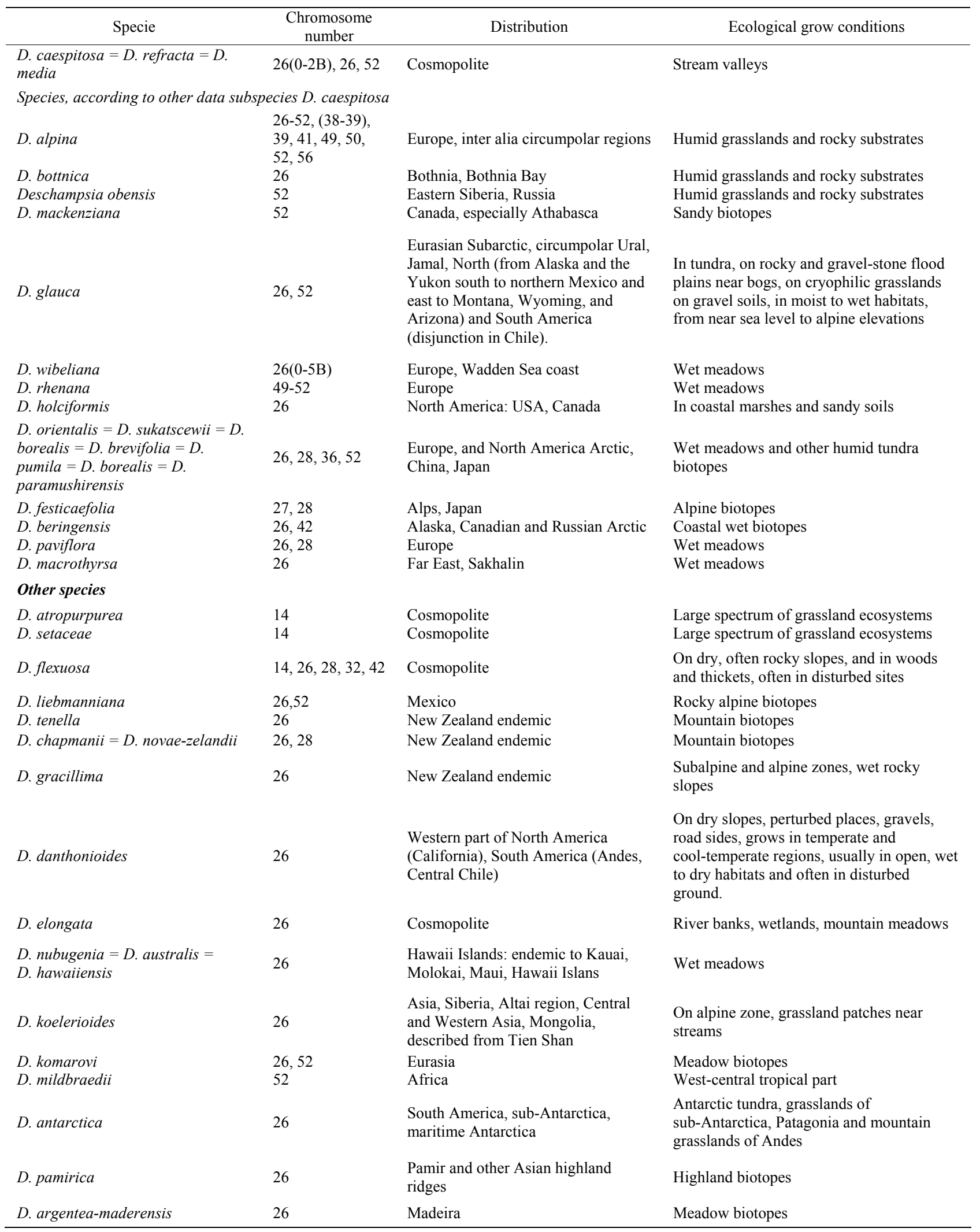




\section{Evolutionary and Phylogenetic Aspects}

While recognizing D. antarctica and C. quitensis as Antarctic indigenous species, the majority of researchers adhere to the hypothesis of post-Pleistocenic colonization of the region by these plants $[5,7,8,30]$. At the same time, the exclusive existence of only these two species and the traits of their high gradual adaptation allow one to suggest that their earlier colonization of the region happened during the Tertiary period [82]. Since $D$. antarctica and $C$. quitensis are by no means invasive and have yet not colonized a number of suitable habitats in the region (for instance $C$. quitensis are absent from all of South Sandwich Islands, D. antarctica on majority of it [16]), it seems reasonable to theorize that the expansive species from the sub-Antarctic, rather than these two, should have colonized the emerging suitable habitats after the ice retreat during the post-Pleistocene transmission. However, provided these species have been early colonists, not only their gradually adaptation but a simple saturation of the Antarctic environment with their diaspores would have given them a selective advantage in surviving the hardship of the Antarctic environment. Concerning the age of these species on Earth in general, and in Antarctica in particular, there are only scanty data. The results of paleobotanical studies indicate that Poaceae, just like Caryophyllaceae, appeared during the late Cretaceous and had spread over the supercontinent Gondwana before it completely separated in the Tertiary. The first findings of grasses and their communities relate to the South American Eocene (45 mya). Although pollen grains have been found in the African Eocene, grass communities appear there only in the late Myocene (14 mya) [83]. The first finding of a pollen grain of Caryophyllaceae-Caryophylloflora paleogenica G. J. Jord. and Macphail-occurred in Australia and New Zealand and relates to the late Cretaceous [84]. This species may well have pertained to any other caryophyllid group sensu lata [8], however true Caryophyllaceae themselves appeared in South America not later than in Myocene [84]. In the case of Poaceae, in Myocene there was an expansion of these $\mathrm{C} 4$ plants over the adjacent territories with a formation of open grass communities [85].

Attempts to describe the directions and timing of the general Antarctic vascular plant species dispersal have been made only for Deschampsia. There are two hypotheses of the initial dispersal of the species of this genus: the northern one, which assumes that the genus developed at high and middle latitudes of Eurasia and only later spread to the south where a secondary speciation center formed, and the southern one with the origin point in South America, which assumes the genus to be very old in the Southern hemisphere [21]. The common clade for South American species together with $D$. antarctica (batched based on molecular genetics data) corroborates the localization of the species creation center of at least this part of the genus near the points of contact between South America and Australia and New Zealand via the Antarctic, which may have been the case all the way up to Pleiocene [21,83]. Based on the general idea by Hooker who admitted in 1851 that modern southern flora might represent remnants of the flora of Gondwana [1], a concept has been coined that $D$. antarctica and $C$. quitensis appeared in the region before Pleistocene. In view of the contact between South America and Antarctica via the chain of the Scotia Islands, dispersal all the way up to the late Tertiary when the Antarctic ice sheet still didn't cover the whole continent can not be excluded [82]. At the same time, the vicissitude of glacial maxima and minima that took place during that period in the maritime Antarctic [86] didn't lead to vegetation extinction, and so might concurrently make for its gradually adaptation (mainly thereby wide distribution and dence seedbank) at the onset of the Pleistocenic maximum. In a reply to this suggestion, it was noted that in case of such an ancient age of these species they should have gone through a significant divergence leading to new younger species and subspecies [8]. Perhaps, one could look for the traces of such a divergence in the previously described close relatedness of the sub-Antarctic species of the genus Colobanthus, as well as in the attempts to isolate 13 species within the genus Colobanthus instead of the two- $C$. quitensis and C. subulatus - from South America [26]. Contrary to what many researchers might expect, such a variability of closely related forms interpreted as separate species might not gain speed to develop further due to the narrow range of ecological constraints a form was obliged to fit in to have a chance to survive in the inclement environment of the Andean highlands or Antarctica gripped by ice.

Still, there remains an open question about the possibility of vascular plants' survival in the region through the glaciation events during Pleiocene-Pleistocene (20 1 mya). Information on the scale of glaciation in the Southern hemisphere would be of much help in answering this question. However, determination of ice boundaries is often complicated due to their erasure or masking by later events [3]. Based on data by Sugden and Clapperton [87] and Law and Burstall [28], Smith notes that Antarctic vegetation could hardly remain to the south of South Georgia and Heard Islands which probably were fully covered with ice [1]. At the same time, a reference to a map of glaciations on the Antarctic Peninsula during the Pleistocenic maximum compiled based on a whole series of publications suggests that the South Shetland, South Orkney, and South Sandwich Islands were outside 
the zone of contiguous ice sheet [88]. Also, although Tatur [89] with a reference to Clapperton [90] presents a map illustrating the total glaciation of King George Island, it still contains areas marked as free of ice. Marsz [91] points out a series of regions on this island which, due to a number of reasons, could not freeze over.

In such conditions, the possibility of the ice-free zonesAntarctic refugia - remaining in the region should be considered [82]. For instance, two territories that have not been covered with ice and a number of invertebrate species that have survived have been demonstrated $[3,92$, 93]. However, in the case of vascular plants of the maritime Antarctic, only the areas close to the ocean which are exposed to the buffering effect of the ocean could probably serve as refugia, as it is this effect that alleviates the climate oscillation [1]. Due to the diverse relief, exposition, and the underlying rock composition, a variety of microclimates form, some of which may be suitable for $D$. antarctica and C. quitensis. This seems to be the only plausible reason why the species are absent from many maritime Antarctic shore areas under the conditions of the progressing warming in the region. There is also evidence that this, together with the geomorphological and other characteristics, hinders ice sheet formation on many maritime Antarctic territories [91]. According to Marsz, this kind of oases can be observed on King George Island. One of them, the Point Thomas oasis, is characterized by some of the largest tufts of Antarctic herb tundra formations in the maritime Antarctic $[32,94]$. The present day area of such oases compared to that of bare vegetation-free morains is relatively small. The oldest peat deposits on sub-Antarctic and Antarctic Islands are known to be of Holocene age (5 - 6 thousand years; [1,3]. However older deposits may have not remained as a result of regular washouts or sliding of large masses of peat into the ocean driven by ice streams and the ice tongues of the many ice encroachments rather than glacial rock overlay.

\section{Molecular Genetics Data}

As part of the discussion on the directions and timing of the Antarctic vascular plants' colonization, a reference to the molecular genetics data should be included which, according to some authors, suggest a relatively recent colonization of the region [8]. Indeed, it is a generally accepted idea that biota of the Antarctic refugia must demonstrate a notable genetic diversity as a result of the accumulation of mutations with their fixation by inbreeding and the absence of gene drift [95]. On the contrary, recent colonists are believed not to have enough time to generate interpopulation diversity and demonstrate the founder effect.

A large amount of data on $D$. antarctica heterogeneity has accumulated from research based on the AFLP method. However, an important limitation of the method is its inability to identify the genomic sequences responsible for the detected heterogeneity. For this reason, interpretation of the results obtained by AFLP may be complicated [96]. The interpretation of the results of earlier $D$. antarctica genetic polymorphism studies have been ambiguous. A study using the AFLP method has demonstrated, according to the authors' interpretation, a low variability- $13 \%$ between populations from Signy Island (the South Orkney Islands) and Anchorage, Lagoon, and Leon Islands that are $1350 \mathrm{~km}$ away from the first one. Nevertheless, AFLP method results inevitably bring about the question of what is the actual age of the divergence a given heterogeneity accounts for. At the same time, a high polymorphism has been revealed between the populations from different parts of Signy Island, and a low one between those from the southern region. Additionally, the absence of identical genotypes was registered in both regions [97].

Chwedorzewska, also based on AFLP, has found a higher interpopulation heterogeneity in $D$. antarctica compared to that of the Arctic species D. brevifolia $\mathrm{R}$. Br. and D. alpina (L.) Roem and Schult. from the Svalbard archipelago, with the latter two species demonstrating clear evidence of being post-Pleistocenic colonists. At the same time, $D$. antarctica populations of maritime Antarctic farther south demonstrated lower heterogeneity than northern populations living in a less hostile environment [98]. Such a pattern, apparently, can be explained by a stepwise dispersal of the species in the region [8]. Concerning the possibility of multiple colonization events, provided several genotypes have remained in different Antarctic oases, their counter-dispersal during the period of milder climate conditions on from the beginning of Holocene may well have made for the pattern obtained by Chwedorzewska. This explanation is corroborated by another two studies on interpopulation polymorphism in D. antarctica, also using AFLP. The co-existance of the two groups of genotypes and intermixed populations has been revealed in a study of the molecular heterogeneity in populations from the Point Thomas oasis (King George Island) [99].

Additionally it has been shown that interpopulation heterogeneity in plants from the Falkland Islands is higher than that between other maritime Antarctic populations that live farther apart from each other. On the other hand, an analysis of heterogeneity in $D$. antarctica from the far more distant South Shetland Islands and Argentine Islands has revealed that the plants from both regions are equally heterogeneous, which didn't allow their clear-cut clustering with further batching them in agreement with their geographic location [100]. The 
higher heterogeneity in northern regions, again, provides evidence of more genetic variants that have formed here, while the heterogeneity level-off in populations from regions farther south may be explained by a northern origin of these populations, which is in accordance with the previous study.

Therefore, AFLP data can suggest the localization of the center of genetic diversity of $D$. antarctica on the north of the maritime Antarctic [97] and the adjacent archipelagos of sub-Antarctic, which, in our opinion, is in good agreement with the possibility that refugia have existed here in which the species might survive glaciations. Such a picture, in the case of Antarctic vascular plants, could well make use of the Wladislaw Szafer's idea of migration relicts as species relict only in some parts of the areal, i.e. those that dispersed from refugia into adjoining regions at a later time [82,101]. In the case of Antarctic plants, survival may have been successful in a number of refugia close to the sea on the South Shetland Islands and the South Orkney Islands, as well as, perhaps, the South Sandwich Islands from which individual plants with relatively heterogeneous (after isolation) genotypes might counter-disperse into both the more southern territories of the maritime Antarctic and the nearest ice-free regions. Preservation of glacial refugia on South Georgia Island has also been suggested [102]. The presence of flowers capable of cross-pollination in $D$. antarctica indicates that gene transfer between the usually cleistogamic populations may also be possible during particularly favorable seasons.

Such data are absent for the second Antarctic vascular plant species, however the notable morphological variability of $C$. quitensis, as well as the concentration of species of this genus in the northern parts of the maritime Antarctic, Scotia and the southern end of South America [26] is in good agreement with the idea of the existence of refugia specifically in this region.

More specific conclusions based on the available body of AFLP data might be expected if it included populations from South America. Investigation of these maternal (apparently in both cases - pre-Pleistocenic and postPleistocenic colonization) locations would probably help to clarify the time of the divergence. However in this case, one should keep in mind that those Andean glaciations, similar to those in Antarctica, significantly restricted the territories suitable for vegetation development. As a result, the territories that became free of ice after the glaciation periods could have been colonized by plants from both the neighboring populations and those transmitted from the regions farther south.

One of the reasons why AFLP data should be approached with a great deal of caution becomes apparent from the studies on genetic heterogeneity in a population of the annual grass Poa annua L., a species which is known to be a transferred weed that appeared near the Polish station Arctowski in the 1980s. Admitting that the station personnel is accountable for transferring the plant from Europe, in contrast to the expected low heterogeneity in this species as a result of the founder effect, Chwedorzewska points out that the actual heterogeneity is surprisingly high $-60 \%$ [103]

A concurrent study of $D$. antarctica from South America, sub-Antarctic, and the maritime Antarctic has been done only with respect to non-coding chloroplast DNA [100]. Only three haplotypes of the chloroplast DNA have been found, with heterogeneity obtained with only a small fraction of primers. Additionally, very large territories were represented with just a few samples in this study. The revealed unique for the South Orkney Islands haplotype $\mathrm{C}$ within the zone of contiguous distribution of haplotype A brings about the idea that plants with different genotypes can neighbor on the same island or a close group of islands. Therefore, the existence of plants bearing these and some as yet unknown haplotypes in other regions can not be ruled out. Based on the revealed haplotype $\mathrm{C}$ unique for the Orkney Islands, one could suggest a possible refugium located here. However, there is evidence of the putative glaciation of the whole area south of $60^{\circ}$ [87]. At the same time, the absence of such evidence from the Indian Ocean side (the Kerguellen and Crozet archipelagos) allows the authors to describe the haplotype formed here as a result of the isolation in refugia near the ice sheet edge [100].

In order to be able to come to safer conclusions about the age of the divergence between species living in South America, sub-Antarctic, and maritime Antarctic, some researchers turned to employing molecular markers that are more use-proven in phylogenetic plots. The authors are aware of only one study in which several specimens of $C$. quitensis from the Chilean Ands and the maritime Antarctic were compared with regards to the internal transcribed spacer (ITC) of ribosomal DNA. The variability of the nucleotide sequence of this, common in taxonomy, region of DNA was only $1.17 \%$ [104].

However 35S rDNA (the nuclear locus coding for 5.8S, $18 \mathrm{~S}$ and $25 \mathrm{~S}$ rRNAs; for review see [105] represents a class of repeated sequences under control of concerted evolution which is responsible for the high degree of homogenization between repeats [106]. The high degree of homogenization and the existence of regions evolving with different rates make $35 \mathrm{~S}$ rDNA a very attractive tool for molecular taxonomy, phylogeography, and population genetics. In particular, comparison of rapidly evolving ITS1 and ITS2 has widely been used for taxonomic reconstructions among members of the same or closely related genera $[107,108]$. 
For instance, Saxifraga paniculata Mitt., which has undoubtedly survived highland glaciations in separate refugia, demonstrates only 14 variable nucleotides $(2.4 \%)$ out of 583 nucleotides of ITC on the interpopulation level [109]. In the Mediterranean plant genus Anthyllis, the species Anthyllis montana L. is known to have evolved in late Pleiocene through early Pleistocene. It differs from its closest species by 5,2, and 17 nucleotide substitutions in ITC. Its intraspecific divergence started only in late Quarternary (0.7 mya) [110]. A similar history, in the case of $D$. antarctica and C. quitensis, could potentially explain the absence of clear-cut species separation for the significant geological time some authors propose [8], as well as the onset of species split in the post-glaciation period, which seems to have taken place in the region with $C$. quitensis. Interestingly, based on the data on interpopulation variability of ITC in 12 plants of $D$. antarctica from 6 sites in the region of the Argentine Islands and 6 sites on King George Island (the South Shetland Islands separated from the former group by $500 \mathrm{~km}$ ), as well as data available from GenBank (http://www.expasy.org), a high degree of identity (96.3\%) between the samples and GenBank data was observed with the total differences between plants from different populations being within several nucleotides [96]. Nonetheless, analogy with the abovementioned Anthyllis montana is hardly possible.

The 12 analyzed samples of $D$. antarctica from both regions seem to have had different genetic origins. The evolutionary ancestral ITS variant and a derived variant have been found in both locations, whereas the most divergent variant has only been detected on King George Island. Therefore, these results demonstrate that genetically distinct plants may co-exist within the same or adjacent populations on Antarctic islands [96]. Similar observations have recently been made for chloroplastic DNA by [100]. Based on these data, a spread of plants with different genotypes closing in on their way during recolonization of post-glacial territories can be assumed. Consequently, the molecular genetics studies carried out on the population level for Antarctic vascular plants so far do not allow us to unambiguously determine the time of D. antarctica and C. quitensis colonization. In view of this, a determination of the precise timing of such a spread, as well as the age of the above-mentioned genotypes, as yet seems problematic. The problems stem from the uncertainties in the applied methods, as well as the insufficiency of the available material, both the living plant samples from the maritime Antarctic and the fossil records. Additionally, it should be admitted that molecular biology studies of these species are so far at the beginning, and this promises many unexpected data to appear in future.

\section{Conclusions}

The unique dispersal and appropriate adaptation of only two species of vascular plants in the natural flora of the Antarctic remains enigmatic. Possible approaches to solve this problem were considered to lie in the domains of the subcellular and molecular levels of organization of plants from different populations of these species. Indeed, complex studies of these aspects in Antarctic vascular plants are only beginning. At the same time, the multifarious data available so far on these species provide evidence that the causes of the success of Deschampsia antarctica and Colobanthus quitensis are not related to any unique adaptations but to their history of migration and adaptation to living in the region. In this paper, it is proposed that the explanation of this phenomenon may lie in of a prolonged spreading of these plants in conditions of gradual worsening in the maritime Antarctic with the alternating development of newly formed ice-sheets thereby a wide distribution and formation of a spatially dispersed seed bank. Both factors could potentially have allowed the two species to survive in sporadic areas that were free of ice sequentially during but a few years. In regard to this, further complex studies of glaciations and microclimates that have been the case in the region during a sequence of glacial events are expected to be the most tempting perspective in the context of the history of the regional flora. And it is only approach employing molecular genetics, population and reproductive biology studies that will be able to explain the high gradually adaptation of these species. A study of the genome evolution of both of the Antarctic genera from different regions of their areal using adequate molecular genetics and other methods is one of the main steps in the future research. At the same time, it would be informative to compare the obtained data with that for the Arctic species of the genus Deschampsia and the genera close to the genus Colobanthus.

\section{Acknowledgements}

We thank anonymous reviewer, A. Rozhok \& M. Rozhok and P. Convey for their friendly help with manuscript preparation and English correction.

\section{REFERENCES}

[1] R. I. L. Smith, "Terrestrial Plant Biology of the Sub- Antarctic and Antarctic," In: R. M. Laws, Ed., Antarctic Ecology, Vol. 1, Academic Press, London, 1984, pp. 61-162.

[2] P. Convey, D. W. Hopkins, S. J Roberts and A. N. Tyler, "Global Southern Limit of Flowering Plants and Moss Peat Accumulation," Polar Research, 2011, in press.

[3] P. Convey, J. A. E. Gibson, C.-D. Hillenbrand, D. A. Hodgson, P. J. A. Pugh, J. L. Smellie and M. I. Stevens, "Antarctic Terrestrial Life-Challenging the History of 
the Frozen Continent?" Biological Reviews, Vol. 83, No. 2, 2008, pp. 103-117. doi:10.1111/j.1469-185X.2008.00034.x

[4] M. W. Holdgate, "Terrestrial Ecology in the Maritime Antarctica," In: R. Caricket, et al., Eds., Biologie Antarctique, Hermann, Paris, 1964, pp. 181-940.

[5] M. Alberdi, L. A. Bravo, A. Gutierrez, M. Gidekel and L. J. Corcuera, "Ecophysilogy of Antarctic Vascular Plants," Physiologia Plantarum, Vol. 115, No. 4, 2002, pp. 479-486. doi:10.1034/j.1399-3054.2002.1150401.x

[6] R. E. Longton, "Vegetation Ecology and Classification in the Antarctic Zone," Canadian Journal of Botany, Vol. 57, No. 20, 1979, pp. 2264-2278. doi:10.1139/b79-273

[7] R. I. L. Smith, "The Enigma of Colobanthus quitensis and Deschampsia antarctica in Antarctica," In: A. H. L. Huiskes, et al., Eds., Antarctic Biology in a Global Context, Backhuys, Leiden, 2003, pp. 234-239.

[8] S. L. Mosyakin, L. G. Bezusko and A. S. Mosyakin, "Origins of Native Vascular Plants of Antarctica: Comments from Historical Phytogeography Viewpoint," $C y$ tology and Genetics, Vol. 41, No. 5, 2007, pp. 54-63.

[9] L. Kappen and B. Schroeter, "18 Plants and Lichens in the Antarctic, Their Way of Life and Their Relevance to Soil Formation," In: L. Beyer and M. Bolter, Eds., Geoecology of Antarctic Ice-Free Coastal Landscapes, Vol. 154, Springler-Verlag, Berlin, 2002, pp. 327-374.

[10] R. I. L. Smith and R. W. M. Corner, "Vegetation of the Arthur Harbour-Argentine Islands Region of the Antarctic Peninsula," British Antarctic Survey Bulletin, No. 33-34, 1973, pp. 89-122.

[11] W. D. Billings and H. A. Mooney "The Ecology of Arctic and Alpine Plants," Biological Reviews of the Cambridge Philosophical Society, Vol. 43, No. 4, 1968, pp. 481-529. doi:10.1111/j.1469-185X.1968.tb00968.x

[12] P. Convey and R. I. L. Smith, "Response of Terrestrial Antarctic Ecosystems to Climate Change," Plant Ecology, Vol. 41, Part 1, 2005, pp. 1-12. doi:10.1007/978-1-4020-4443-4_1

[13] J. A. Fowbert and R. I. L. Smith, "Rapid population increases in native vascular plants in the Argentine Islands Antarctic Peninsula," Arctic and Alpine Research, Vol. 26, No. 3, 1994, pp. 290-296. doi:10.2307/1551941

[14] R. I. L. Smith, "Plant Colonization Response to Climate Change in the Antarctic," Folia Facultatis Scientiarum Naturalium Universitatis Masarykiana Brunensis, Geographia, Vol. 25, No. 19-33, 2001, pp. 19-33.

[15] P. Convey, "Maritime Antarctic climate Change Signals from Terrestrial Biology," Antarctic research series, Vol. 79, 2003, pp. 145-158. doi:10.1029/AR079p0145

[16] P. Convey and R. I. L. Smith, "Geothermal Bryophyte Habitats in the South Sandwich Islands, Maritime Antarctic," Journal of Vegetation Science, Vol. 17, No. 4, 2006, pp. 529-538. doi:10.1111/j.1654-1103.2006.tb02474.x

[17] J. Turner, S. R. Colwell, G. J. Marshall, T. A. Lachlan-Cope, A. M. Carleton, P. D. Jones, V. Lagun, P. A. Reid and S. Iagovkina, "Antarctic Climate Change during the Last 50 Years," International Journal of Climatology,
Vol. 25, No. 3, 2005, pp. 279-294. doi:10.1002/joc.1130

[18] M. A. Olech, "Expansion of Alien Vascular Plant Poa annua L. in the Vicinity of the Henryk Arctowski station-A Consequence of Climate Change?" 29th International Polar Symposium, The Functioning of Polar Ecosystems as Viewed against Global Environmental Changes, Kraków, 19-21 September 2003, pp. 89-90.

[19] M. A. Olech and K. J. Chwedorzewska, "Population Growth of Alien Species Poa annua L. at the Vicinity of H. Arctowski Station (South Shetland Is)," SCAR/IASC IPY Open Science Conference, St. Petersburg, 8-11 July 2008, pp. 214-215.

[20] J. A. Edwards, "Studies in Colobanthus quitensis (Kunth.) Bartl. and Deschampsia Antarctica Desv.: VI. Reproductive Performance on Signy Island," British Antarctic Survey Bulletin, No 28, 1974, pp. 67-86.

[21] J. Chiapella, "Infrageneric Classification and Phylogeny of Deschampsia (Poaceae: Avenae)," Problems of Evolution, Vol. 5, 2003, pp. 221-231.

[22] J. Chiapella, "A Molecular Phylogenetic Study of Deschampsia (Poaceae: Avenae) Inferred from Nuclear ITS and Plastid trnL Sequence Data: Support for Recognition of Avenella and Vahlodea," Taxon, Vol. 56, No. 1, 2007, pp. 55-64.

[23] D. P. Fernández Souto, S. A. Catalano, D. Tosto, P. Bernasconi, A. Sala , M. Wagner and D. Corach, "Phylogenetic Relationships of Deschampsia antarctica (Poaceae): Insights from Nuclear Ribosomal ITS," Plant Systematics and Evolution, Vol. 261, No. 1-4, 2006, pp. 1-9.

[24] S. Cardone, P. Sawatani, P. Rush, A. García, L. Poggio and G. Schrauf "Karyological Studies in Deschampsia antarctica Desv. (Poaceae)," Polar Biology, Vol. 32, No. 3, 2008. doi:10.1007/s00300-008-0535-8

[25] L. Frey, "Avenella: A Genus of the Aveneae (Poaceae) Worthy of Recognition," Fragmenta Floristica et Geobotanica, No. 7, Supplement, 1999, pp. 27-32.

[26] D. M. Moore, "Studies in Colobanthus quitensis (Kunth.) Bartle. and Deschampsia antarctica Desv. II. Taxonomy, Distribution and Relationships," British Antarctic Survey Bulletin, No. 23, 1970, pp. 63-80.

[27] B. V. Sneddon, "The Taxonomy and Breeding System of Colobanthus squarrosus (Caryophyllaceae)," New Zealand Journal of Botany, Vol. 37, No. 2, 1999, pp. 195-204. doi:10.1080/0028825X.1999.9512627

[28] P. G. Law and T. Burstall, "Heard Island. Australian National Antarctic Research Expedition," Interim Reports, No. 7, 1953, p. 20.

[29] R. W. M. Corner, "Studies in Colobanthus quitensis (Kunth) Bartl. and Deschampsia antarctica Desv.: IV. Distribution and Reproductive Performance in the Argentine Islands," British Antarctic Survey Bulletin, No. 26, 1971, pp. 41-50.

[30] D. M. Greene and A. Holtom, "Studies in Colobanthus quitensis (Kunth.) Bartle. and Deschampsia antarctica Desv III. Distribution, Habitats and Performance in the Antarctic Botanical Zone," British Antarctic Survey Bulletin, No. 26, 1971, pp. 1-29. 
[31] R. I. L. Smith and S. Poncet, "Deschampsia antarctica and Colobanthus quitensis in the Terra-Firma Islands," British Antarctic Survey Bulletin, No. 74, 1987, pp. 31-35.

[32] V. Komárkova, S. Poncet and J. Poncet, "Two Native Vascular Plants, Deschampsia antarctica Desv. and Colobanthus quitensis (Kunth.) Bartl: A New SouthernMost Locality and Other Localities in the Antarctic Peninsula Area," Arctic and Alpine Research, Vol. 17, No. 4, 1985. pp. 401-416.

[33] V. Komárkova, S. Poncet and J. Poncet "Additional and Revisited Localities of Vascular Plants, Deschampsia antarctica Desv. and Colobanthus quitensis (Kunth.) Bartl. in the Antarctic Peninsula Area," Arctic and Alpine Research, Vol. 22, No. 1, 1990, pp. 108-113. doi: $10.2307 / 1551725$

[34] R. I. L. Smith, "Terrestrial and Freshwater Biotic Components of the Western Antarctic Peninsula," In: R. M. Ross, et al., Eds., Foundation for Ecological Research West of the Antarctic Peninsula, Vol. 70, American Geophysical Union, Antarctic Research Series, 1996, pp. 15-59.

[35] V. F. De Carvalho, C. D. Pinheiro and P. A. Batista, "Characterization of Plant Communities in Ice-Free Areas Adjoining the Polish Station H. Arctowski, Admiralty Bay, King George's Island, Antarctica," 2006. http://www.dna.gov.ar/CIENCIA/SANTAR04/CD/PDF/2 02BB.PDF

[36] I. Parnikoza, I. Dykyy, I. Kozeretska, O. Tyschenko and D. Inozemtseva, "Current State of Antarctic Herb Tundra Formation of Argentine Islands and Nearest Archipelago," Ukraine in Antarctica-National Priorities and Global Integration, Kyiv, 23-25 May 2008, p. 31.

[37] I. Yu. Parnikoza, D. M. Inozemtseva, O. V. Tyschenko, O. Mustafa and I. A. Kozeretska, "Antarctic Herb Tundra Colonization Zones in the Context of Ecological Gradient of Glacial Retreat," Ukrainian Botany Journal, Vol. 65, No. 4, 2008, pp. 504-511.

[38] R. Bargagli, "Antarctic Ecosystems Environmental Contamination, Climate Change, and Human Impact," In: M. M. Galdwell, et al., Ed., Ecological Studies, SpringerVerlag, Berlin, Vol. 175, 2005, pp. 1-395.

[39] D. Yu. Vlasov, E. V. Abakumov, M. A. Nadporozhanskaya, N. V. Kovsh, V. S. Krylenkov, V. V. Lukin and E. V. Safronova, "Lithosols of King George Island, Western Antarctica," Eurasian Soil Science, Vol. 38, No. 7, 2005, pp. 681-687.

[40] J. Smykla, J. Wołek, and A. Barcikowski, "Zonation of Vegetation Related to Penguin Rookeries on King George Island, Maritime Antarctic," Arctic, Antarctic, and Alpine Research, Vol. 39, No. 1, 2007, pp. 143-151. doi:10.1657/1523-0430(2007)39[143:ZOVRTP]2.0.CO;2

[41] M. Krywult, J. Smykla and A. Wincenciak, "Influence of Ornithogenic Fertilization on Nitrogen Metabolism of the Antarctic Vegetation," 29 International Polar Symposium. The Functioning of Polar Ecosystems as Viewed against Global Environmental Changes, Kraków, 19-21 September 2003, pp. 123-127.

[42] I. Yu. Parnikoza, N. Yu. Miryuta, D. N. Maidanyuk, S. A.
Loparev, S. G. Korsun, I. G. Budzanivska, T. P. Shevchenko, V. P. Polischuk, V. A. Kunakh and I. A. Kozeretska, "Habitat and Leaf Cytogenetic Characteristics of Deschampsia antarctica Desv. in Maritime Antarctic," Polar Science, Vol. 1, No. 2-4, 2007, pp. 121-127. doi:10.1016/j.polar.2007.10.002

[43] S. G. Korsun, I. A. Kozeretska, I. Yu. Parnikoza, L. I. Shkarivska, K. Ya. Luhovska and I. I. Klymenko, "The Effect of Natural and Anthropogenic Factors on the Chemical Composition of Soils in the Maritime Antarctics," Agroekologichnyi Zhurnal, No. 4, 2008, pp. 20-25.

[44] D. M. Moore, "Flora of Tierra del Fuego," Anthony Nelson Oswestry, UK, 1983.

[45] A. Corte, "Fertilidad de las Semillas Fanerogamas Que Crecen en Cabo Primavera (Costa de Danco), Peninsula Antarctica," Contribución del Instituto Antártico Argentino, No. 65, 1961, pp. 1-16.

[46] G. Borgström, "Formation of Cleistogamic and Chasmogamic Flowers in Wild Violets as a Photoperiodic Response," Nature, Vol. 144, 1939, pp. 514-515.

[47] R. H. M. Langer and D. Wilson, "Environmental Control of Cleistogamy in Prairie Grass (Bromus unioloides H.B.K.)," New Phytologist, Vol. 64, No. 1, 2006, pp. 80-85. doi:10.1111/j.1469-8137.1965.tb05377.x

[48] I. Parnikoza, O. Kozeretska and I. Kozeretska, "Is a Translocation of Indigenous Plant Material Successful in the Maritime Antarctic?" Polarforshung, Vol. 78, No. 1-2, 2008, pp. 25-27.

[49] J A. Edwards, "Studies in Colobanthus quitensis (Kunth) Bartl. and Deschampsia antarctica Desv.: VII. Cyclic Changes Related to age in Colobanthus quitensis," British Antarctic Survey Bulletin, No. 40, 1975, pp. 1-6.

[50] I. A. Kozeretska, I. Yu. Parnikoza, O. Mustafa, O. V. Tyschenko, S. G. Korsun and P. Convey, "Development of Antarctic Herb Tundra Vegetation near Arctowski Station, King George Island," Polar Science, Vol. 3, No. 4, 2010, pp. 254-261. doi:10.1016/j.polar.2009.10.001

[51] P. Convey, "Reproduction of Antarctic Flowering Plants," Antarctic Science, Vol. 8, No. 2, 1996, pp. 127-134.

[52] J. B. McGraw and T. A. Day, "Size and Characteristic of a Natural Seed Bank in Antarctica," Arctic and Alpine Research, Vol. 29, No. 2, 1997, pp. 213-216.

[53] R. Upson, K. K. Newsham and D. J. Read, "Root-Fungal Associtions of Colobanthus quitensis and Deschampsia antarctica in the Maritime and Subantarctic," Arctic, Antarctic, and Alpine Research, Vol. 40, No. 3, 2008, pp. 592-599.

[54] M. Philipp, J. Böcher, O. Mattson and S. R. J. Woodell, “A Quantitative Approach to the Sexual Reproductive Biology and Population Structure of Some Arctic Flowering Plants: Dryas integrifolia, Silene acaulis and Ranunculus nivalis," Meddeleser om Grønland, Bioscience, Vol. 34, 1990, pp. 1-60.

[55] A. Mantovani and R. C. Vieira, "Leaf Micromorphology of Antarctic Pearlwort Colobanthus quitensis (Kunth) Bartl," Polar Biology, Vol. 23, No. 8, 2000, pp. 531-538.

[56] A. Barcikowski, J. Czaplewska, I. Giełwanowska, P. Loro, 
J. Smykla and K. Zarzycki, "Deschampsia antarctica (Poaceae)-The Only Native Grass from Antarctica," In: L. Frey, Ed., Studies on grasses in Poland, W. Szafer Institute of Botany, Polish Academy of Science, Kraków, 2001, pp. 367-377.

[57] I. Gielwanowska and E. Szczuka, "New Ultrastructural Features of Organelles in Leaf Cells of Deschampsia antarctica Desv," Polar Biology, Vol. 28, No. 12, 2005, pp. 951-955.

[58] L. Kappen, "Plant Activity under Snow and Ice, with Particular Reference to Lichens," Arctic, Vol. 46, No. 4, 1993, pp. 297-302.

[59] P. O. Montiel, "Soluble Carbohydrates (Trehalose in Particular) and Cryoprotection in Polar Biota," Cryoletters, Vol. 21, No. 2, 2000, pp. 83-90.

[60] A. V. Kolesnichenko and V. K. Voynikov, "Low Temperature Stress Proteins in Plants," Art-Press, Irkutsk, 2003.

[61] N. Olave-Concha, S. Ruiz-Lara, X. Munoz, L. A. Bravo and L. J. Corcuera, "Accumulation of Dehydrin Transcripts and Protein in Response to Abiotic Stresses in Deschampsia antarctica," Antarctic Science, Vol. 16, No. 2, 2004, pp. 175-184.

[62] M. A. Reyes, L. J. Corcuera and L. Cardemil, "Accumulation of HSP70 in Deschampsia antarctica Desv. Leaves under Thermal Stress," Antarctic Science, Vol. 15, No. 3, 2003, pp. 345-352.

[63] C. J. Doucet, L. Byass, L. Elias, D. Worrall, M. Smallwood and D. J. Bowles, "Distribution and Characterization of Recrystallization Inhibitor Activity in Plant and Lichen Species from the UK and Maritime Antarctic," Cryobiology, Vol. 40, No. 3, 2000, pp. 218-227.

[64] U. P. John, R. M. Polotnianka, K. A. Sivakumaran, O. Chew, L. Mackin, M. J. Kuiper, J. P. Talbot, D. G. Nugent, J. Mautord, G. E. Schrauf and G. C. Spangenberg, "Ice Recrystallization Inhibition Proteins (IRIPs) and Freeze Tolerance in the Cryophilic Antarctic Hair Grass Deschampsia antarctica Desv," Plant, Cell and Environment, Vol. 32, No. 4, 2009, pp. 336-348.

[65] M. Gidekel, L. Destefano-Beltrán, P. García, L. Mujica, P. Leal, M. Cuba, L. Fuentes, L. A. Bravo, L. J. Corcuera, M. Alberdi, I. Concha and A. Gutiérrez, "Identification and Characterization of Three Novel Cold Acclimation-Responsive Genes from the Extremophile Hair Grass Deschampsia antarctica Desv," Extremophiles, Vol. 7, No. 6, 2003, pp. 459-469.

[66] E. Pérez-Torres, A. García, J. Dinamarca, M. Alberdi, A. Gutiérrez, M. Gidekel, A. G. Ivanov, N. P. A. Hüner, L. J. Corcuera and L. A. Bravo, "The Role of Photochemical Quenching and Antioxidants in Photoprotection of Deschampsia antarctica," Functional Plant Biology, Vol. 31, No. 7, 2004, pp. 731-741.

[67] A. Zuniga-Feest, D. R. Ort, A. Gutierrez, M. Gidekel, L. A. Bravo and L. J. Corcuera, "Light Regulation of SucrosePhosphate Synthase Activity in the Grass Deschampsia antarctica," Photosynthesis Research, Vol. 111, 2005, pp. $55-65$.

[68] U. A. Bravo, N. Ulloa, G. E. Zuniga, A. Casanova, L. J.
Corcuera and M. Alberdi, "Cold Resistance in Antarctic angiosperm," Physiologia Plantarum, Vol. 111, No. 1, 2001, pp. 55-65.

[69] N. M. Topchii "The Role of the Light Collecting Complex in Higher Plant Adaptation to Light Environment," PhD Thesis, Kyiv Taras Schevchenko National University, Kyiv, 2006.

[70] N. Yu. Taran, O. A. Okanenko, I. P. Ozheredova, I. A. Kozeretska and N. B. Svetlova "The Conposition of Lipid and Pigment-Protein Complexes of Photosynthetic Membranes in Deschampsia antarctica Desv.," Reports of the National Academy of Sciences of Ukraine, No. 2, 2009, pp. 173-178.

[71] N. B. Svyetlova, A. A. Okanenko and N. Yu. Taran, "Impact of Ultraviolet Radiation on Deschampsia antarctica Desv. One of Vascular Plant Species in Antarctica," SCAR/IASC IPY Open Science Conference, St. Petersburg, 8-11 July 2008, p. 197.

[72] C. Lütz, M. Blassing and D. Remias, "Different Flavanoid Patterns in Deschampsia antarctica and Colobanthus quitensis from the Marine Antarctic," In: C. Wiencke, et al., Eds., Reports on Polar and Marine Research. The Antarctic Ecosystem of Potter Cove King George Island (Isla 25 de Mayo), Vol. 571, 2008, pp. 192-198.

[73] I. P. Ozheredova and I. A. Kozeretska, "Prediction of the Function of Amino Acid Products from Deschampsia antarctica Based on Homology with Known Proteins," 4th International Conference on Factors of Experimental Evolution of Organisms, Kyiv, 22-26 September 2008, pp. 190-195.

[74] R. E. Krogulevitch and T. S. Rostovceva, "Chromosome Numbers of Plants from Siberia and the Far East," Nauka, Novosibirsk, 1984.

[75] A. A. Fedorova, et al., "Chromosome Numbers of Flowering Plants," Nauka, Leningrad, 1969.

[76] B. G. Purdy and R. J. Bayer, "Genetic Diversity in the Tetraploid Sand Dune Endemic Deschampsia mackenziana and Its Widespread Diploid Progenitor D. caespitosa (Poaceae)," American Journal of Botany, Vol. 82, No. 1, 1995, pp. 121-130.

[77] F. Albers, "Karyologishe und Genomatische Veranderungen Innerhalb der Graser-Subtripben Aristaveninae und Airinae," Berichte der Deutschen Botanischen Gesellschaft, No. 91, 1978, pp. 693-697.

[78] V. P. Seledets and N. S. Probatova, "Ecological Areal and Some Problems of Differentiation in the Family Poaceae from the Russian Far East," Problems of Evolution, No. 5, Dalnauka, Vladivostok, 2003, p. 220.

[79] K. K. Nkongolo, A. Deck and P. Michael, "Molecular and Cytological Analysis of Deschampsia cespitosa Population from Northern Ontario (Canada)," Genome, Vol. 44, No. 5, 2001, pp. 818-825.

[80] V. I. Adonin, I.Yu. Parnikoza, S. S. Kyrychenko, I. A. Kozeretska and V. A. Kunakh, "Mixoploidy in Deschampsia antarctica of the Maritime Antarctic," Abstracts of the Proceedings in Honour of 300-Years from K. Linnaeus Born, Lugansk, Elton-2, May 2007, p. 74. 
[81] S. S. Kiryachenko, I. A. Kozeretska and S. Rakusa-Sushchevski, "Deschampsia antarctica: Genetic and Molecular Biology Aspects of Distribution in Antarctica," Cytology and Genetics, Vol. 39, No. 4, 2005, pp. 75-80.

[82] I. Yu. Parnikoza, D. N. Maidanuk and I. A. Kozeretska "Are Deschampsia antarctica Desv. and Colobanthus quitensis (Kunth) Bartl. Migratory Relicts?" Cytology and Genetics, Vol. 41, No. 4, 2007, pp. 36-40.

[83] R. Jones, "The Biogeography of the Grasses and Lowland Grasslands of South-Eastern Australia," 1994. http://home.vicnet.net.au/ iffa/GPCconf/Jones1.pdf

[84] G. J. Jordan and M. K. Macphail, “A Middle-Late Eocene Inflorescence of Caryophyllaceae from Tasmania, Australia," American Journal of Botany, Vol. 90, No. 5, 2003, pp. 761-768.

[85] C. P. Osborne, "Atmosphere, Ecology and Evolution: What Drove the Miocene Expansion of $\mathrm{C}_{4}$ Grasslands?" Journal of Ecology, Vol. 96, No. 1, 2007, pp. 35-45.

[86] A. Gazdzicki, "Cenozoic Glacial History and Biota Evolution: Evidence from South Shetlands and Antarctic Peninsula," 22nd International Polartagung, Jena, 18-24 September 2005, pp. 55.

[87] D. E. Sugden and C. M. Clapperton, "The maximum Ice Extent on Island Groups in the Scotia Sea, Antarctica," Quarternary Research, Vol. 7, No. 2, 1977, pp. 268-282.

[88] D. E. Sugden, M. J. Bentley and C. O. Cofaigh, "Geological and Geomorphological Insights into Antarctic Ice Sheet Evolution," Philosophical Transactions of the Royal Society A, Vol. 364, No. 1844, 2006, pp. 1607-1625.

[89] A. Tatur, "Ornithogenic Ecosystems in the Maritime Antarctic-Formation Development and Aisintegration," Warsaw University Press, Warsaw, 2005, pp. 27-47.

[90] C. M. Clapperton, "Quaternary Glaciations in the Southern Ocean and Antarctic Peninsula Area," Quaternary Science Reviews, Vol. 9, No. 2-3, 1990, pp. 229-252.

[91] A. A. Marsz, "The Origin and Classification of Ice Free Areas ("Oases") in the Region of the Admiralty Bay (King George Island, The South Shetland Islands, West Antarctica)," In: P. Prošek, et al., Eds. Ecology of the Antarctic Coastal Oasis, Masaryk University, Brno, 2001, pp. 7-18.

[92] D. Yu. Bolshiyanov, "The Last Glacial Maximum and a Minor Ice Age in Antarctica," Research Series of the Scientific Conference "Russia in Antarctica", Arctic and Antarctic Scientific Research Instutute, Saint-Petersburg, 12-14 April 2006, pp. 50-51.

[93] M. I. Stevens, P. Greenslade, I. D. Hogg and P. Sunnucks, "Southern Hemisphere Springtails: Could Any Have Survived Glaciations of Antarctica," Molecular biology and Evolution, Vol. 23, No. 5, 2006, pp. 874-882.

[94] D. C. Lindsay, "Vegetation of the South Shetland Islands," British Antarctic Survey Bulletin, No. 25, 1971, pp. 59-83.

[95] V. Le Corre, S. Dumoulin-Lappegue and A. Kerner, "Genetic Variation at Allozyme and RAPD Loci in Sessile Oak Quercus petrea (Matt.) Liebl.: The Role of His- tory and Geography," Molecular Ecology, Vol. 6, No. 6, 1997, pp. 549-529.

[96] R. A. Volkov, I. A. Kozeretska, S. S. Kyryachenko, I. O. Andreev, D. N. Maidanyuk, I. Yu. Parnikoza and V. A. Kunakh, "Molecular Evolution and Variability of ITS1ITS2 in Populations of Deschampsia antarctica from Two Regions of the Maritime Antarctic," Polar Science, Vol. 4, No. 3, 2010, pp. 469-478. doi:10.1016/i.polar.2010.04.011

[97] R. Holderegger, I. Stehlic, R. I. L. Smith and R. J. Abbott, "Population of Antarctic Hairgrass (Deschampsia antarctica) Show Low Genetic Diversity," Arctic, Antarctic and Alpine Research, Vol. 35, No. 2, 2003, pp. 214-217.

[98] K. J. Chwedorzewska, "Preliminary Genetic Study on Species from Genus Deschampsia from Antarctic (King George I.) and Arctic (Spitsbergen)," Polar Bioscience, No. 19, 2006, pp. 142-147.

[99] K. J. Chwedorzewska, P. T. Bednarek and J. Puchalski, "Molecular Variations of Antarctic Grass Deschampsia antarctica Desv. from King George Island (Antarctica)," Acta Societatis Botanicorum Poloniae, Vol. 73, No. 1, 2004, pp. 23-29.

[100] M. Van der Wouw, P. Van Dijk and A. D. H. L. Huiskes, "Regional Genetic Diversity Patterns in Antarctic Hairgrass (Deschampsia antarctica Desv.)," Journal of Biogeography, Vol. 35, No. 2, 2007, pp. 365-376.

[101] W. Szafer, "General Plant Geography," Polskie Wydawnictwo Naukowe, Warszawa, 1975.

[102] N. Van der Putten, H. Stieperaere, C. Verbruggen and R. Ochyra, "Holocene Paleoecology and Climate History of South Georgia (Sub-Antarctica) Based on Macrofossil Record of Bryophytes and Seeds," The Holocene, Vol. 14, No. 3, 2004, pp. 382-392.

[103] K. J. Chwedorzewska, "Poa annua L. in Antarctic: Searching for the Source of Introduction," Polar Biology, Vol. 31, No. 3, 2008, pp. 263-268.

[104] E. Gianoli, P. Inostoza, A. Zuniga-Feest, M. Reyes-Diaz, L. A. Cavieres, L. A. Bravo and L. J. Corcuera, "Ecotypic Differentiation in Morphology and Cold Resistance in Populations of Colobanthus quitensis (Caryophyllaceae) from Andes of Central Chile and the Maritime Antarctic," Arctic, Antarctic, and Alpine Research, Vol. 36, No. 4, 2004, pp. 484-489.

[105] R. A. Volkov, F. J. Medina, U. Zentgraf and V. Hemleben, "Molecular Cell Biology: Organization and Molecular Evolution of rDNA, Nucleolar Dominance and $\mathrm{Nu}$ cleolus Structure," In: K. Esser, et al., Eds., Progress in Botany, Vol. 65, Springer Verlag, Berlin, 2004, pp. 106-146.

[106] R. Volkov, S. Kostishin, F. Ehrendorfer and D. Schweizer, "Comparative Study of the Organization and Molecular Evolution of External Transcribed Spacer Region in rDNA of Two Nicotiana Species," Plant Systematics and Evolution, Vol. 201, No. 1-4, 1996, pp. 117-129.

[107] G. W. Grimm, M. Schlee, N. Y. Komarova, R. A. Volkov and V. Hemleben, "Low-Level Taxonomy and Intrageneric Evolutionary Trends in Higher Plants," Nova Acta 
Leopoldina, Vol. 92, No. 342, 2005, pp. 129-145.

[108] J. Jobst, K. King and V. Hemleben, "Molecular Evolution of the Internal Transcribed Spacers (ITS1 and ITS2) and Phylogenetic Relationships among Species of Cucurbitaceae," Molecular Phylogenetics and Evolution, Vol. 9, No. 2, 1998, pp. 204-219.

[109] C. Reisch, "Climatic Oscillations and the Fragmentation of Plant Populations Genetic Diversity within and Among Populations of the Glacial Relict Plants Saxifraga paniculata (Saxifragaceae) and Sesleria albicans (Poaceae)," Dissertationes Botanicae Series, Band 359, Gebrüder Borntraeger Verlag, Berlin, 2002, pp. 1-113.

[110] M. Kropf, J. W. Kadereit and H. P. Comes, "Late Quaternary Distributional Stasis in the Submediterranean Mountain Plant Anthyllis montana L. (Fabaceae) Inferred from ITS Sequences and Amplified Fragment Length Polymorphism Markers," Molecular Ecology, Vol. 11, No. 3, 2002, pp. 447-463. 